\title{
PENERAPAN ANALISIS REGRESI SPLINE UNTUK MENDUGA HARGA CABAI DI JAKARTA*
}

\author{
Hestiani Wulandari ${ }^{1}$, Anang Kurnia ${ }^{2 \ddagger}$, Bambang Sumantri ${ }^{3}$, \\ Dian Kusumaningrum ${ }^{4}$, Budi Waryanto ${ }^{5}$
}

\author{
${ }^{1}$ PT PIKMIAP GLOBAL EKSPRESS, Indonesia, hestiwlndri@gmail.com \\ ${ }^{2}$ Dept. of Statistics, Bogor Agricultural University (IPB), Indonesia, anangk@apps.ipb.ac.id \\ ${ }^{3}$ Dept. of Statistics, Bogor Agricultural University (IPB), Indonesia, bambangsu@ipb.ac.id \\ ${ }^{4}$ Business Mathematics, Universitas Prasetiya Mulya, Indonesia, dian.kusumaningrum@gmail.com \\ ${ }^{5}$ Division Data Food Crops and Livestock, Ministry of Agriculture, Indonesia, budi_w@pertanian.go.id \\ $\ddagger$ corresponding author
}

\section{Indonesian Journal of Statistics and Its Applications Vol 1 No 1 (2017), 1 - 12}

Copyright @ 2017 Hestiani Wulandari, Anang Kurnia, Bambang Sumantri, Dian Kusumaningrum, Budi Waryanto. This is an open-access article distributed under the Creative Commons Attribution License, which permits unrestricted use, distribution, and reproduction in any medium, provided the original work is properly cited.

\begin{abstract}
The chili is an important commodity in Indonesia, which has a fairly large price fluctuations. Fluctuations in prices often raises the risk of loss even have contributed to inflation. Chili price data is time series data that is not independent between observations (autocorrelation) and do not spread to normal. In addition, chili price data does not have the diversity of homogeneous data. One method that can be used to predict the pattern of the data is spline regression. The data used in this study is data the average weekly price of chili in Jakarta from January, 2010 to October, 2015. The best spline model is a second order spline models with three knots. The model has a value of Mean Absolute Percentage Error (MAPE) of $9.57 \%$ and determination coefficient of $86.41 \%$. The model obtained in this research is already well in predicting the pattern of the chili price, but it was only able to predict well for a period of one month. Prediction chili prices in Jakarta for November are in the range of Rp 35.565.
\end{abstract}

Keywords: chili price, regression, spline.

${ }^{*}$ Received Jun 2017; Accepted Jul 2017; Published online on Oct 2017 


\section{Pendahuluan}

Penduduk Indonesia sebagian besar bermata pencaharian sebagai petani. Salah satu komoditas holtikultura yang dihasilkan adalah Cabai. Cabai merupakan komoditas holtikultura yang memiliki peranan penting di Indonesia. Produksi cabai di Indonesia pada tahun 2014 mengalami peningkatan menjadi 1.03 juta ton dari sekitar 61.73 ribu ton pada tahun 2013. Berdasarkan data dari Kementrian Pertanian dan BPS (2011) dalam Farid dan Subekti (2012) terjadi peningkatan produksi cabai dari tahun 2005 sampai dengan tahun 2009 di Pulau Jawa sebesar 5.8 per tahun. Berbeda dengan kondisi tersebut, provinsi Jakarta mulai tahun 2009 sudah tidak memiliki hasil produksi cabai. Menurut Saptana dan Ar-Rozi (2012) total konsumsi cabai di Jakarta mencapai 65.30 ton/hari. Jumlah konsumsi masyarakat Jakarta yang relatif besar dengan kondisi tidak memiliki hasil produksi menjadikan Jakarta sebagai daerah tujuan utama pemasaran cabai di Indonesia. Pemenuhan kebutuhan tersebut didatangkan dari daerah lain seperti Jawa Barat, Jawa Tengah, Jawa Timur dan Sumatera Utara sebagai daerah sentra produksi.

Cabai dikonsumsi oleh rumah tangga maupun industri. Rumah tangga memanfaatkan cabai sebagai bahan makanan seperti bahan rempah, penghias makanan, bahan pewarna, aroma dan pemberi rasa pedas. Industri makanan memanfaatkan cabai menjadi berbagai macam produk olahan seperti saos cabai, sambel cabai, pasta cabai, bubuk cabai, cabai kering, dan bumbu instant. Cabai juga dimanfaatkan pada industri obat-obatan dalam pembuatan krim obat gosok antirematik maupun dalam bentuk Koyo Cabai. Penggunaan yang cukup luas tersebut menyebabkan komoditas ini memiliki nilai ekonomis tinggi.

Cabai merah merupakan salah satu komoditas yang memiliki fluktuasi harga cukup besar. Ketidakpastian harga menyebabkan resiko kerugian bagi petani maupun pelaku perdagangan (Sugiharta, 2002). Selain itu, fluktuasi harga cabai juga memberikan dampak secara nasional. Cabai merah merupakan salah satu komoditas utama yang memiliki kontribusi terhadap terjadinya inflasi sebesar $0.32 \%$ pada tahun 2010 ([BI] Bank Indonesia, 2013). Oleh sebab itu, diperlukan informasi mengenai pola harga cabai agar resiko kerugian ataupun kontribusi terhdap inflasi dapat berkurang. Selanjutnya apabila pola tersebut telah diketahui, maka model tersebut dapat digunakan untuk memperkirakan harga di masa mendatang yang diharapkan mendekati atau sama dengan harga sebenarnya di waktu tersebut. Kumpulan data harga cabai merah merupakan data deret waktu. Data deret waktu adalah sekumpulan data observasi yang disusun berdasarkan waktu (Katijaya dan Suparti, 2013). Menurut Sumaryanto (2009) data harga cabai merah memiliki sifat heteroskedastis. Sifat tersebut disebabkan karena kondisi harga cabai yang tidak stabil, cendrung bervariasi dan sulit diprediksi. Hal tersebut apabila terjadi secara terus-menerus dengan fluktuasi harga yang besar dapat mengakibatkan nilai rata-rata dan ragam tidak konstan sehingga pemodelan untuk memprediksi data tidak dapat diselesaikan dengan metode parametrik yang ketat dengan asumsi. Oleh karena itu perlu dibentuk model prediksi melalui pendekatan nonparametrik. Salah satu model dengan pendekatan nonparametrik yang sering digunakan untuk menduga bentuk kurva adalah regresi spline.

Regresi spline adalah suatu metode yang digunakan untuk mendapatkan dugaan kurva regresi melalui pendekatan pengepasan data. Metode ini merupakan model polinomial dengan sifat tersegmen yang memberikan fleksibiltas lebih tinggi. Sifat tersebut memungkinkan model regresi spline dapat disesuaikan dengan karakteristik lokal data. Keunggulan dari model dengan pendekatan spline adalah model yang 
dibentuk dapat mempertimbangkan pola data yang naik atau turun tajam dengan bantuan titik knot. Titik knot adalah titik pertemuan dari pola perilaku fungsi spline pada selang berbeda (Agustini, 2011). Knot optimum ditentukan bedasarkan nilai General Cross Validation (GCV) terkecil (Suparti, 2013). Kriteria yang digunakan untuk melihat model spline terbaik adalah model dengan knot optimum yang mempunyai MAPE terkecil.

Regresi spline pernah diteliti oleh Suparti (2013) untuk memprediksi data inflasi di Indonesia. Selain itu, pada tahun yang sama Suparti, juga Katijaya dan Sudarsono menggunakan regresi spline untuk melakukan pemodelan kurs Rupiah terhadap mata uang Euro dan Dolar Amerika Serikat. Berdasarkan hasil dari penelitian tersebut, regresi spline sangat baik digunakan dalam memprediksi suatu pola data yang memiliki karakteristik yang cenderung berbeda. Dalam makalah ini harga cabai di Jakarta dimodelkanmenggunakan Analisis Regresi Spline.

\section{Metodologi}

\subsection{Sumber Data}

Data yang digunakan dalam penelitian ini merupakan data sekunder yang diperoleh dari Pusat Data dan Sistem Informasi (Pusdatin), Kementerian Pertanian Indonesia. Data tersebut merupakan data rataan harga cabai mingguan di Jakarta mulai bulan Januari tahun 2010 sampai bulan Oktober tahun 2015. Data yang digunakan untuk melakukan pendugaan pola harga cabai adalah data pada bulan Januari tahun 2010 sampai bulan Agustus tahun 2015. Metode pengumpulan data yang digunakan adalah survei panel. Survei panel adalah survei dengan tujuan mengamati perubahan yang dialami individu dari waktu ke waktu. Contoh ditentukan secara acak untuk individu yang sama pada interval yang tetap (Nurdini, 2006).

\subsection{Tahapan Analisis Data}

Tahapan yang dilakukan pada penelitian ini adalah:

1. Melakukan eksplorasi data untuk melihat bentuk kurva atau pola data.

2. Mendefinisikan data rataan harga cabai mingguan menjadi dua peubah yaitu $y_{t}$ sebagai peubah respon dan $y_{t-1}$ sebagai peubah prediktor dengan t merupakan amatan waktu ke $1,2, . . n$.

Menurut Katijaya dan Suparti (2013) pada pemodelan regresi untuk data deret waktu konsep yang mendasari pemodelan tersebut, yaitu: Model (T). Model $\left\{Y_{t}, t \geq 1\right\}$ merupakan deret waktu yang telah diobservasi kemudian dalam memprediksi deret waktu satu dimensi $Y_{t+1}$ dapat digambarkan ke dalam model $\mathrm{f}(\mathrm{x})=\mathrm{E}(\mathrm{Y}-\mathrm{X}=\mathrm{x})$. Nilai $Y_{t-1}$ sebagai $X_{i}$ dan nilai $Y_{t}$ sebagai $Y_{i}$ dengan $\mathrm{t}=2,3, \ldots, \mathrm{n}$. Selanjutnya, prediksi untuk deret waktu $\left\{Y_{t+1}\right\}$ dapat dilakukan dengan regresi pemulusan untuk $\left\{X_{i}, Y_{i}\right\}_{i=1}^{n}=\left\{Y_{t-1}, Y_{t}\right\}_{t=1}^{n}$ seperti memprediksi deret waktu $Y_{t}$ dengan menduga $\mathrm{f}(\mathrm{x})$ untuk dua dimensi deret waktu $\left\{X_{i}, Y_{i}\right\}_{i=1}^{n}$.

3. Menentukan letak titik knot

Penentuan letak titik knot pada penelitian ini menggunakan tiga cara. Pertama, membagi banyak amatan sama banyak dengan rumus sebagai berikut (S, 2009). 


$$
\text { knots }_{i}=\frac{i}{(k+1)} \times n ; i=1,2, \ldots, k
$$

k merupakan banyak titik knot yang digunakan. Setelah posisi titik didapatkan akan dilihat nilai x pada posisi titik tersebut. Nilai x tersebut yang akan digunakan dalam analisis. Kedua, membagi jarak sama besar antar knot menggunakan rumus sebagai berikut (Wu dan Zhang, 2006).

$$
\text { knots }_{i}=\frac{(b-a) \times i}{(k+1)}+a ; i=1,2, \ldots, k
$$

a merupakan nilai minum data, $\mathrm{b}$ adalah nilai maksimum data. Cara terakhir adalah penentuan menggunakan seleksi knot. Knot dipilih menggunakan seluruh data sebagai kandidat knot. Penentuan knot dengan cara ini menggunakan paket $\mathrm{R}$ yaitu freeknotsplines.

4. Melakukan regresi spline untuk mendapatkan dugaan kurva pada orde satu, dua dan tiga. Analisis regresi spline dilakukan menggunakan software R 3.1.0.

Sintaks yang digunakan dalam penelitian ini merupakan modifikasi dari sintaks yang telah dibuat oleh S (2009) dengan perbedaan pada peubah prediktor yang digunakan.

5. Menentukan titik knot optimum berdasarkan nilai GCV terkecil.

6. Menentukan regresi spline terbaik berdasarkan nilai MAPE terkecil.

7. Membandingkan hasil dugaan yang didapatkan dengan nilai aktual.

8. Melakukan validasi data hasil dari dugaan model regresi spline terbaik.

9. Membandingkan hasil validasi (prediksi) dengan nilai aktual.

10. Melakukan prediksi harga cabai di Jakarta. Prediksi harga cabai diperoleh dengan memasukkan nilai aktual harga cabai sebelumnya ke dalam model terbaik yang didapatkan menggunakan Microsoft Excel.

\section{Hasil dan Pembahasan}

Plot data rataan harga cabai merah besar mingguan selama periode Januari 2010 sampai dengan Agustus 2015 dapat dilihat pada Gambar 1. Berdasarkan gambar tersebut terlihat bahwa harga cabai di Jakarta memiliki fluktuasi cukup besar.

Harga cabai tertinggi yang pernah terjadi di tingkat konsumen adalah sebesar Rp 86800 dan harga terendah yang pernah terjadi adalah Rp 11440. Harga tertinggi terjadi pada minggu ke dua bulan Desember tahun 2014, sedangkan harga terendah terjadi pada minggu pertama bulan Agustus tahun 2011. Harga cabai yang tinggi pada waktu tersebut terjadi akibat adanya kenaikan harga bahan bakar minyak (BBM) yang mengakibatkan naiknya harga transportasi. Hal tersebut berdampak pada bertambahnya biaya distribusi sehingga harga cabai juga mengalami kenaikan harga. Peristiwa meletusnya gunung merapi pada daerah penghasil cabai turut menyumbang kenaikan harga cabai tersebut. Harga minimum pada minggu pertama bulan Agustus 


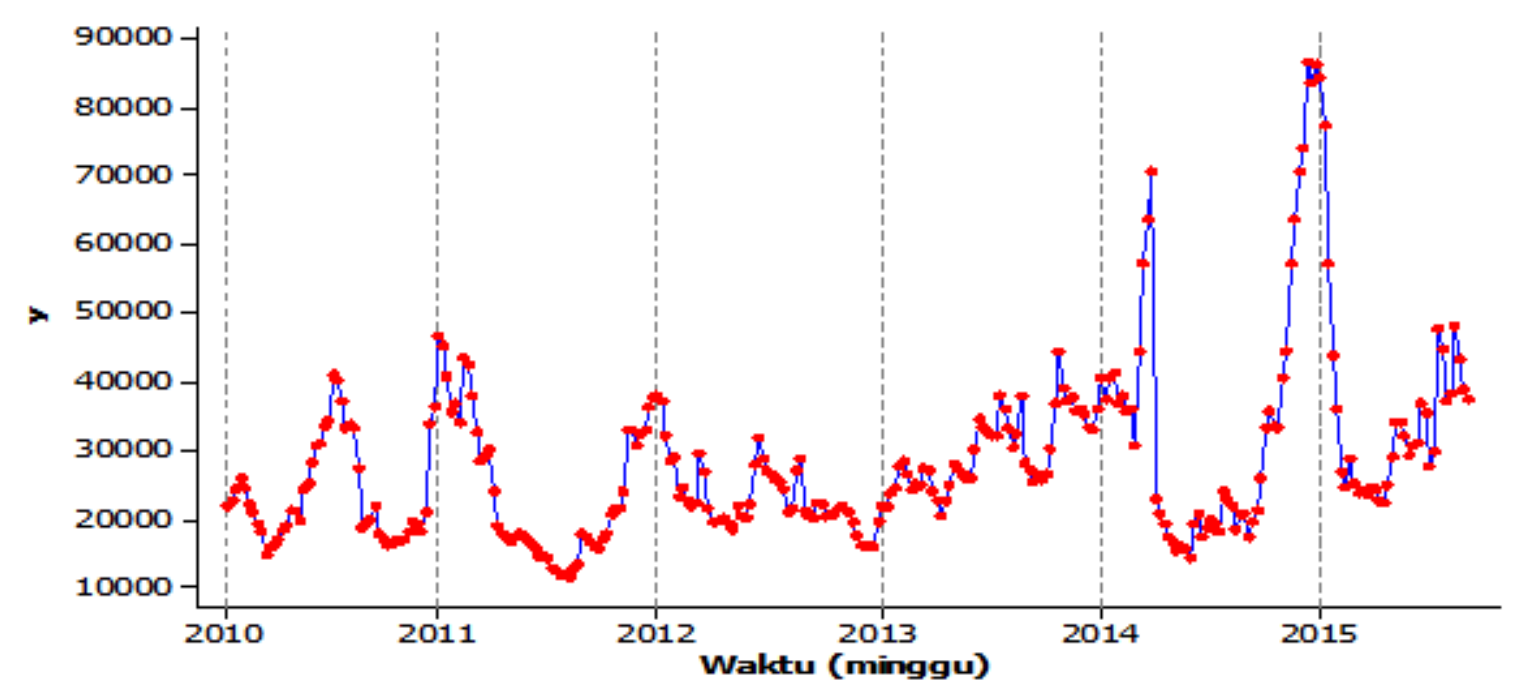

Gambar 1: Plot data harga cabai tahun 2010-2015

2011 dialami ketika jumlah pasokan cabai melimpah dari hasil panen raya. Hal tersebut menyebabkan harga cabai di pasaran menjadi rendah.

Rata-rata harga jual cabai merah besar sejak tahun 2010 hingga tahun 2015 di tingkat konsumen berada pada kisaran harga Rp 27684 per kg. Kenaikan harga cabai merah tertinggi yang pernah terjadi sejak tahun 2010 hingga pertengahan tahun 2015 yaitu sebesar Rp 18106. Kejadian tersebut terjadi pada bulan Juli minggu pertama menuju minggu kedua pada tahun 2015. Hal tersebut terjadi ketika harga cabai merah besar meningkat dari Rp 29760 per kg menjadi Rp 47867 per kg. Peningkatan harga tersebut disebabkan oleh adanya kenaikan jumlah permintaan cabai menjelang hari Raya Idul Fitri. Selain itu, peningkatan harga juga terjadi mulai bulan November tahun 2014 sampai akhir tahun 2014. Kenaikan harga pada waktu tersebut disebabkan oleh adanya pengumuman mengenai Harga BBM bersubsidi yang akan naik mulai tanggal 19 November 2014. Awal tahun 2015 pada bulan Januari dan Februari harga cabai mulai mengalami penurunan karena pasokan cabai sudah mulai kembali normal.

Penurunan harga cabai terbesar sejak tahun 2010-2015 terjadi pada minggu keempat bulan Maret menuju minggu kelima bulan Maret tahun 2014. Harga turun sebesar Rp 47680 per kg yaitu dari Rp 70680 per kg menjadi Rp 23000 per kg. Turunnya harga cabai tersebut disebabkan oleh adanya peningkatan pasokan cabai merah pada bulan Maret 2014 sebesar 13.87\%, yaitu dari 136 ton/hari menjadi 155 ton/hari. Peningkatan pasokan cabai disebabkan oleh beberapa daerah sentra produksi seperti Blitar, Rembang, Madura, Muntilan, Jawa Barat serta dari sebagian daerah Kediri (Pare) yang sebelumnya mengalami bencana Gunung Kelud sudah mulai memasuki masa panen raya.

\subsection{Penentuan Letak Titik Knot}

Penentuan titik knot dilakukan dengan menggunakan tiga cara, yaitu (a) membagi jumlah amatan sama banyak, (b) membagi jarak antar knot sama besar dan (c) seleksi. Penentuan posisi knot dengan ketiga cara tersebut dilakukan setelah peubah prediktor dan peubah respon diplotkan. Adapun plot antara peubah prediktor dengan peubah respon dapat dilihat pada Gambar 2.

Berdasarkan Gambar 2 terlihat satu amatan yang berbeda cukup jauh dari amatan 


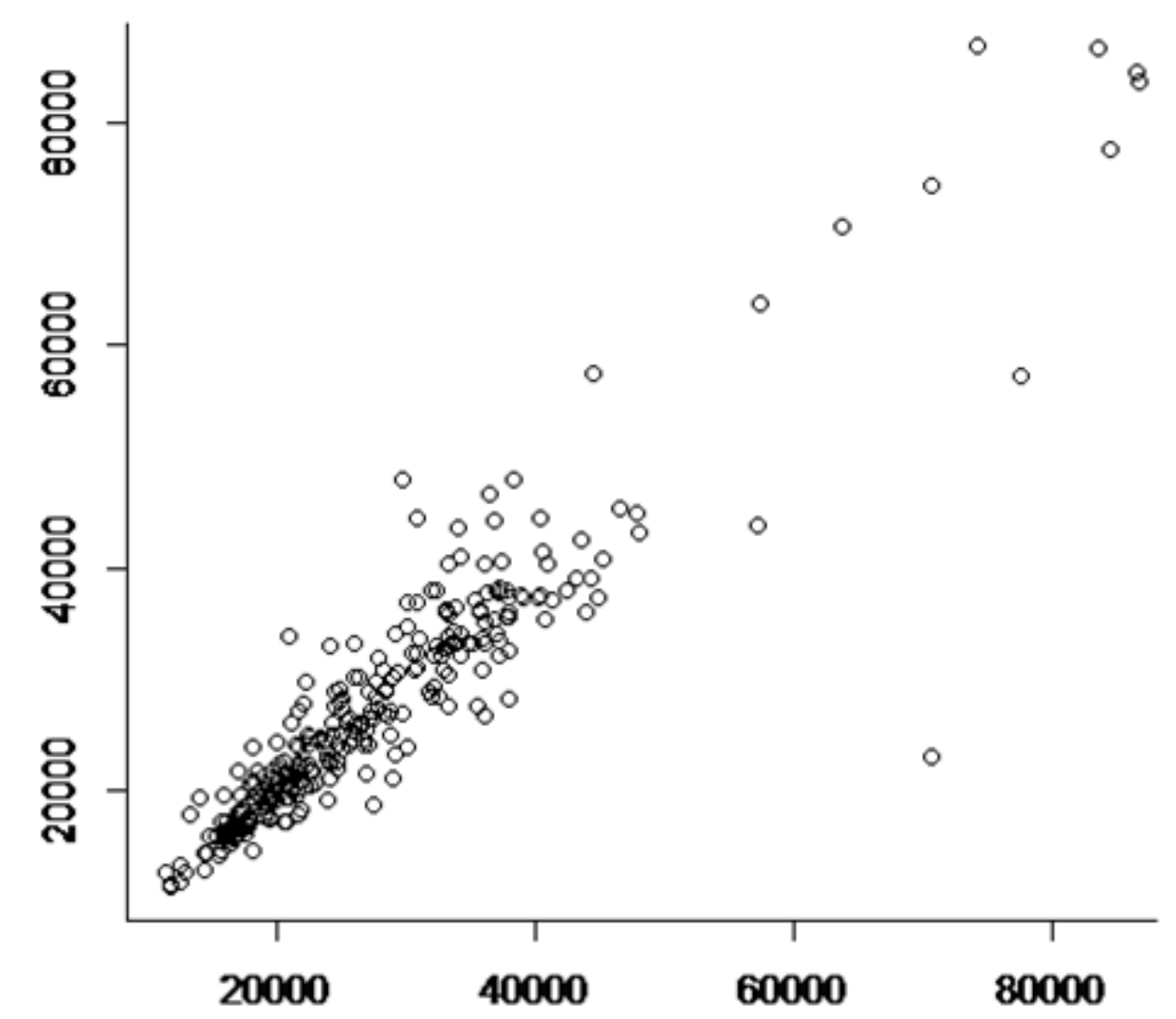

Gambar 2: Plot antara harga sebelumnya $\left(Y_{t-1}\right)$ sebagai peubah prediktor dengan harga $\left(Y_{t}\right)$ sebagai peubah respon

yang lain. Amatan tersebut merupakan amatan pada bulan Maret minggu ketiga tahun 2014. Harga cabai (y) mengalami penurunan cukup besar dari harga sebelumnya (x) yaitu sebesar Rp 47680. Harga cabai pada minggu kedua bulan Maret 2014 sebesar Rp 70680 turun menjadi Rp 23000 pada minggu ketiga.

Pemilihan jumlah knot dapat dilakukan dengan melihat pola pada data yang akan dilakukan pendugaan. Terdapat dua cara untuk menentukan jumlah knot yang digunakan yaitu menggunakan jumlah knot yang sedikit karena alasan kesederhanaan model atau menggunakan jumlah knot yang banyak. Penggunaan knot dengan jumlah banyak biasanya diterapkan pada data dengan pola yang kompleks. Berdasarkan Gambar 2 bentuk kurva dari plot tersebut cukup sederhana sehingga tidak memerlukan jumlah knot yang banyak. Adapun posisi knot yang didapatkan dengan membagi jumlah amatan sama banyak dan membagi jarak sama besar dapat dilihat pada Tabel 1. Penentuan knot dengan cara seleksi terdapat pada Tabel 2.

Posisi knot hasil penetuan dengan kedua cara pada Tabel 1 akan digunakan untuk semua orde, yaitu orde satu, dua dan tiga. Tabel 1 menunjukkan posisi knot dengan penentuan jumlah amatan sama banyak berada disekitar harga Rp 20000 sampai Rp 30000. Hal tersebut disebabkan karena sebagian besar amatan berada pada rentang harga tersebut seperti yang terlihat pada Gambar 2.

Berdasarkan Tabel 2 dapat dilihat bahwa penentuan dengan cara seleksi menghasilkan posisi yang sama untuk orde satu dan tiga. Posisi knot yang didapatkan untuk orde dua juga tidak berbeda jauh dengan orde satu dan tiga. Pendekatan dengan dua dan tiga 
Tabel 1: Tabel posisi knot dengan cara jumlah amatan sama banyak (a) dan jarak antar $\operatorname{knot}(b)$.

\begin{tabular}{crccc}
\hline Penentuan knot & Knot & \multicolumn{4}{c}{ Letak knot } \\
& & 1 & 2 & 3 \\
\hline a & 1 & 24920 & & \\
& 2 & 21080 & 30650 & \\
& 3 & 19560 & 24920 & 33360 \\
b & 1 & 49120 & & \\
& 2 & 36560 & 61680 & \\
& 3 & 30280 & 49120 & 67960 \\
\hline
\end{tabular}

Tabel 2: Posisi knot dengan cara seleksi

\begin{tabular}{crccc}
\hline Orde & Knot & \multicolumn{3}{c}{ Letak knot } \\
& \multicolumn{1}{c}{1} & 2 & 3 \\
\hline 1,3 & 1 & 76211 & & \\
& 2 & 63798 & 63802 & \\
& 3 & 63799 & 67008 & 70681 \\
2 & 1 & 30800 & & \\
& 2 & 63804 & 70680 & \\
& 3 & 63798 & 70672 & 74279 \\
\hline
\end{tabular}

knot berada disekitar harga Rp 60000 sampai Rp 70000.

\subsection{Regresi Spline}

Setelah posisi knot dari ketiga cara didapatkan, tahapan berikutnya adalah melakukan pemilihan titik optimum pada masing-masing orde. Pemilihan titik optimum didasarkan pada knot yang menghasilkan nilai GCV terkecil pada orde tersebut (Tabel 3).

Tabel 3: Nilai GCV hasil tiga cara yaitu (a) jumlah amatan sama besar, (b) jarak sama besar dan (c) seleksi.

\begin{tabular}{crrrr}
\hline Penentuan knot & Knot & \multicolumn{3}{c}{ Nilai GCV } \\
& & \multicolumn{1}{c}{ Orde 1 } & Orde 2 & Orde 3 \\
\hline a & 1 & 262.998 & 263.227 & 261.808 \\
& 2 & 262.205 & 262.662 & 261.712 \\
& 3 & 262.531 & 262.122 & 261.744 \\
& & & & \\
b & 1 & 263.586 & 262.526 & 261.296 \\
& 2 & 263.088 & 261.329 & 257.851 \\
& 3 & 261.345 & 255.906 & 256.108 \\
c & 1 & 262.367 & 262.925 & 259.909 \\
& 2 & 262.583 & 257.015 & 257.610 \\
& 3 & 262.317 & 253.444 & 250.749 \\
\hline
\end{tabular}

Berdasarkan Tabel 3 terlihat bahwa nilai GCV yang dihasilkan dengan ketiga cara tersebut hampir sama. Pendekatan regresi spline dengan satu ataupun tiga knot tidak memberikan perbedaan hasil yang besar. Titik optimum pada orde satu, dua dan tiga 
dengan cara seleksi (c) dan jarak sama besar (b) didapatkan ketika regresi spline menggunakan pendekatan tiga knot. Titik optimum untuk orde satu dan tiga dengan cara (a) didapatkan ketika regresi menggunakan pendekatan dengan dua knot sedangkan untuk orde dua menggunakan tiga knot.

Setelah knot optimum untuk setiap orde pada masing-masing cara diketahui, maka tahapan berikutnya adalah melakukan pemilihan model terbaik pada masing-masing cara penentuan posisi knot. Model terbaik adalah model dengan nilai MAPE terkecil dengan titik optimum. Tabel 4 menunjukkan nilai MAPE yang didapatkan dari hasil pemilihan dengan knot optimum.

Tabel 4: Nilai MAPE dengan knot optimum pada setiap orde dengan tiga penentuan knot yaitu: (a) amatan sama banyak, (b) jarak sama besar, dan (c) seleksi.

\begin{tabular}{crrr}
\hline Penentuan knot & Orde & Knot & Nilai MAPE \\
\hline a & 1 & 2 & 9.665 \\
& 2 & 3 & 9.658 \\
b & 3 & 2 & 9.672 \\
& 1 & 3 & 9.656 \\
& 2 & 3 & 9.703 \\
c & 3 & 3 & 9.598 \\
& 1 & 3 & 9.665 \\
& 2 & 3 & 9.688 \\
& 3 & 3 & 9.57 \\
\hline
\end{tabular}

Sama halnya dengan nilai GCV yang didapatkan, nilai MAPE dengan knot optimum yang didapatkan juga memiliki hasil yang hampir sama. Nilai tersebut berada disekitar nilai 9.60 dan 9.70. Nilai MAPE terkecil dengan penentuan knot (a) diperoleh pada orde dua dengan tiga knot. Penentuan dengan cara (b) menghasilkan nilai MAPE minimum ketika regresi menggunakan pendekatan dengan tiga knot pada orde dua. Regresi spline pada orde tiga dengan tiga knot dengan penentuan knot (c) menghasilkan nilai MAPE terkecil.

Berdasarkan hasil tersebut, model terbaik bagi harga cabai di Jakarta dengan penentuan knot berdasarkan jumlah amatan sama besar memiliki nilai MAPE sebesar $9.66 \%$. Model tersebut ditunjukkan pada persamaan berikut.

$\hat{y}_{i}=-(5.5 E+0.2)+1.16 x_{i}-(5.82 E-06) x_{i}^{2}+(2.24 E-05)\left(x_{i}-19560\right)_{+}^{2}-(3.35 E-$ $05)\left(x_{i}-24920\right)_{+}^{2}+(1.83 E-05)\left(x_{i}-33360\right)_{+}^{2}$

Model terbaik dengan penentuan knot berdasarkan jarak antara dua knot sama besar memiliki nilai MAPE sebesar $9.60 \%$. Model tersebut ditunjukkan pada persamaan.

$\hat{y}_{i}=(6.58 E+03)+(1.27 E-01) x_{i}+(4 E-05) x_{i}^{2}-(5.86 E-10) x_{i}^{3}+(1.15 E-09)\left(x_{i}-\right.$ $30280)_{+}^{3}-(1.99 E-09)\left(x_{i}-49120\right)_{+}^{3}+(7.41 E-09)\left(x_{i}-67960\right)_{+}^{3}$

Persamaan berikut merupakan model terbaik yang didapatkan dengan penentuan posisi knot menggunakan seleksi dengan nilai MAPE sebesar 9.57\%.

$\hat{y}_{i}=-(4.05 E+03)+1.52 x_{i}-(1.78 E-05) x_{i}^{2}+(1.72 E-10) x_{i}^{3}-(7.56 E-08)\left(x_{i}-\right.$ $63799)_{+}^{3}+(1.89 E-07)\left(x_{i}-67008\right)_{+}^{3}-(1.36 E-07)\left(x_{i}-70681\right)_{+}^{3}$

Berdasarkan hasil diatas, ketiga model yang dihasilkan sudah cukup baik untuk menggambarkan pola data harga cabai di Jakarta. Hal tersebut dapat dilihat dari nilai MAPE yang dihasilkan relatif sama. Perbedaan terbesar nilai MAPE ketiga model tersebut hanya sebesar 0.09. Apabila dilihat dari nilai MAPE terkecil, maka model terbaik bagi harga cabai di Jakarta adalah model hasil penentuan posisi knot dengan 
cara seleksi. Model tersebut merupakan model regresi spline orde tiga dengan pendekatan tiga knot. Adapun knot yang digunakan yaitu Rp 63799, Rp 67008 dan Rp 70681.
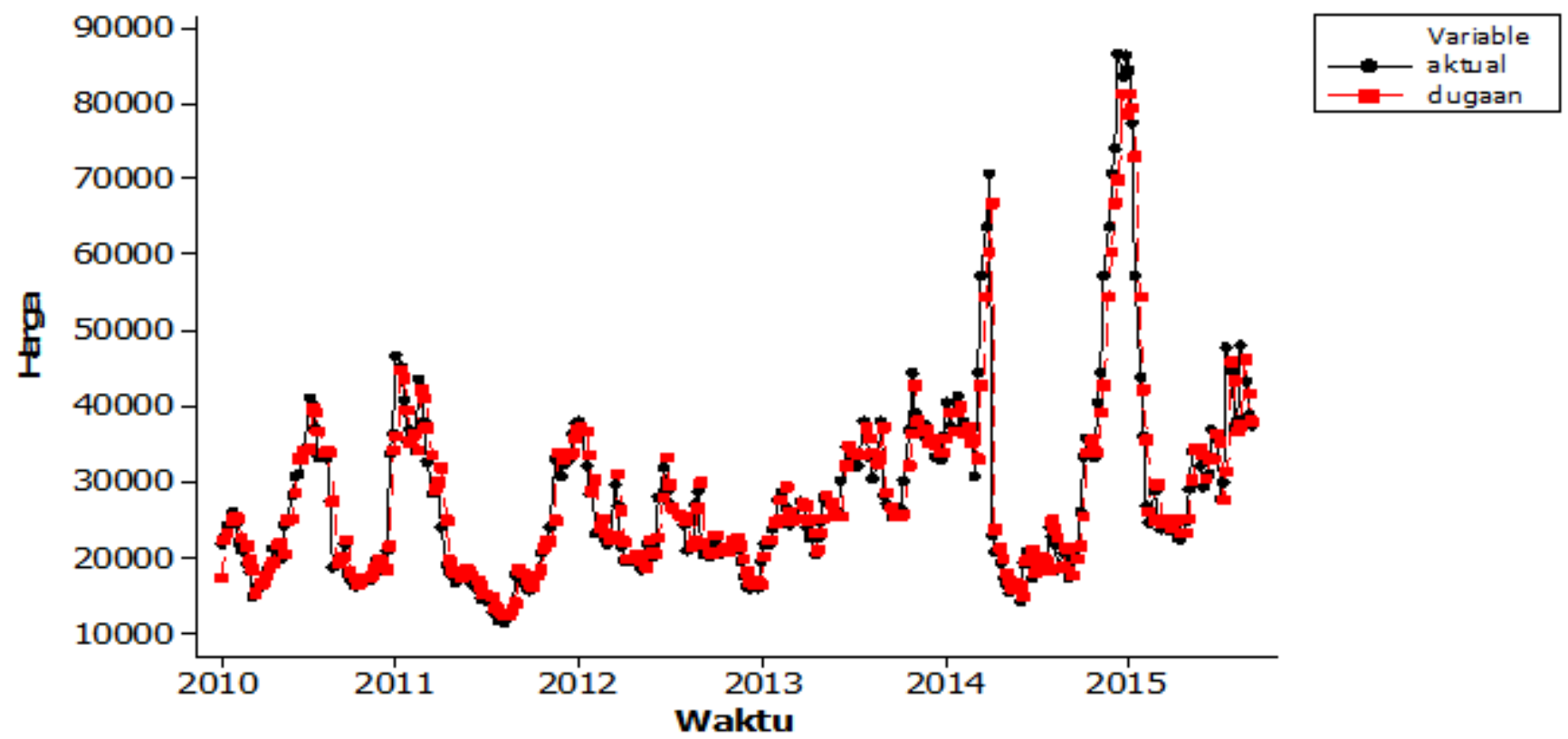

Gambar 3: Plot perbandingan antara harga aktual dengan dugaan harga cabai setelah dikembalikan terhadap waktu $(\mathrm{t})$

Gambar 3 memperlihatkan dugaan kurva regresi spline dihasilkan cukup baik dalam menggambarkan pola data harga cabai. Nilai dugaan yang dihasilkan sudah dapat mengikuti pola dan mendekati nilai aktual harga cabai. Dugaan model tersebut memiliki nilai MAPE sebesar $9.57 \%$. Selain itu, Nilai koefisien determinasi $\left(R^{2}\right)$ yang didapatkan sebesar $86.41 \%$. Hal ini berarti keragaman harga cabai sebelumnya mampu menerangkan sebesar $86.41 \%$ terhadap harga cabai. Berdasarkan hasil diatas maka secara keseluruhan model yang didapatkan dari dugaan kurva sudah baik meskipun model yang didapatkan relatif lebih sulit untuk dimengerti oleh awam. Model juga relatif lebih sulit apabila dikerjakan dengan cara manual. Akan tetapi dengan kemajuan teknologi dan perangkat lunak untuk menganalisis suatu data, hal tersebut membuat pengerjaan lebih mudah dilakukan.

\subsection{Validasi hasil dugaan model terbaik}

Tahapan selanjutnya adalah melakukan validasi data berdasarkan dugaan model regresi spline terbaik. Adapun nilai MAPE hasil prediksi dapat dilihat pada Tabel 5. Validasi tersebut dilakukan pada jangka waktu satu minggu, satu bulan dan dua bulan.

Berdasarkan Tabel 5 terlihat bahwa hasil prediksi yang didapatkan untuk satu minggu dan satu bulan kedepan sangat baik. Hal tersebut dapat dilihat dari nilai MAPE yang dihasilkan kecil. Akan tetapi, hasil prediksi untuk jangka waktu dua bulan ke depan belum cukup baik karena nilai MAPE yang dihasilkan cukup besar yaitu sebesar $26 \%$ sehingga kesalahan yang dihasilkan juga cukup besar. Oleh karena itu, dapat disimpulkan bahwa 
Tabel 5: Nilai MAPE hasil validasi data berdasarkan dugaan model terbaik untuk periode waktu satu minggu, satu bulan dan dua bulan.

\begin{tabular}{lll}
\hline Periode & Keterangan & $\begin{array}{l}\text { Nilai } \\
\text { MAPE }\end{array}$ \\
\hline $\begin{array}{l}\text { Satu } \\
\text { minggu }\end{array}$ & $\begin{array}{l}\text { Minggu ke-1 bulan } \\
\text { Satu bulan }\end{array}$ & $0.97 \%$ \\
Bulan September & $7.31 \%$ \\
Dua bulan & Bulan Oktober & $26 \%$ \\
\hline
\end{tabular}

dugaan model regresi spline terbaik yang didapatkan baru dapat memprediksi harga cabai dengan baik untuk jangka waktu satu bulan.

Model tidak dapat digunakan untuk memprediksi jangka panjang. Hasil prediksi akan baik apabila data bisa didapatkan dengan cepat atau diperbarui secara terus-menerus. Metode ini cocok digunakan untuk jenis data yang memiliki kemudahan untuk memperolehnya seperti data saham. Data saham bergerak setiap hari dan mudah untuk diakses. Penggunaan metode kurang tepat untuk memprediksi jangka panjang jenis data yang pengumpulannya menggunakan metode survei. Data yang dikumpulkan dengan cara survei membutuhkan waktu cukup lama karena dikumpulkan dari beberapa tempat. Hal tersebut menyebabkan akses untuk memperbarui data dengan cepat tidak dapat dilakukan.

Berdasarkan hasil validasi diatas, model regresi spline terbaik yang didapatkan mampu memprediksi untuk jangka waktu sebulan. Prediksi harga cabai untuk bulan November 2015 ditunjukkan pada Tabel 6.

Tabel 6: Prediksi harga cabai bulan November 2015

\begin{tabular}{ll}
\hline Waktu & Prediksi \\
\hline Minggu ke-1 & 22727 \\
Minggu ke-2 & 23364 \\
Minggu ke-3 & 23985 \\
Minggu ke-4 & 24586 \\
Minngu ke-5 & 25164 \\
\hline
\end{tabular}

Prediksi harga cabai di Jakarta untuk bulan November 2015 berada pada kisaran harga Rp 22000 sampai dengan Rp 25000. Hasil dari prediksi harga untuk jangka waktu satu bulan tersebut bermanfaat bagi sisi konsumen dan pedagang. Akan tetapi hasil ini belum dapat dimanfaatkan oleh petani. Petani membutuhkan prediksi harga cabai untuk jangka waktu paling tidak tiga bulan untuk memprediksi harga jual cabai ketika panen dilakukan. Hal tersebut akan berpengaruh terhadap pengambilan keputusan untuk melakukan penanaman cabai agar resiko kerugian dapat berkurang. 


\section{Simpulan dan Saran}

\subsection{Simpulan}

Penggunaan regresi spline untuk mendapatkan dugaan kurva harga cabai di Jakarta sudah dapat menghasilkan dugaan model yang baik. Hal tersebut dapat dilihat dari nilai dugaan harga cabai yang dihasilkan tidak jauh berbeda dengan nilai aktual harga cabai. Dugaan model regresi spline terbaik adalah regresi spline dengan pendekatan tiga knot pada orde tiga. Model tersebut memiliki nilai MAPE sebesar $9.57 \%$ dan koefisien determinasi sebesar $86.41 \%$.

Model sangat baik untuk memprediksi harga satu minggu ke depan dengan nilai MAPE sebesar 0.97\%. Model masih dapat memprediksi dengan baik untuk jangka waktu satu bulan dengan nilai MAPE sebesar 7.31\%. Prediksi data akan baik apabila dilakukan dengan memperbarui data secara berkala agar hasil prediksi yang didapatkan juga baik dalam menggambarkan harga diwaktu mendatang. Prediksi harga cabai pada minggu pertama bulan November 2015 adalah Rp 37078. Harga cabai di Jakarta untuk bulan November 2015 diperkirakan berada pada kisaran harga Rp 35565.

\subsection{Saran}

Perlu penelitian lanjutan dengan mencari model peramalan melalui pendekatan metode lain yang dapat mempertimbangkan berbagai kejadian sebagai penyebab fluktuasi harga cabai ini. Salah satu metode peramalan yang dapat dicoba adalah analisis interfensi ataupun analisis dekomposisi, yang dapat mengidentifikasikan tiga komponen secara terpisah sebagai pola dasar dalam data deret waktu. Ketiga komponen tersebut adalah kecenderungan (trend), siklik (cyclical), dan faktor musiman (seasonal factor) sebagai bentuk dari fluktuasi harga tersebut.

\section{Daftar Pustaka}

Agustini, T. (2011). Analisis Regresi Spline Kuadratik, Matematika dan Pedidikan Karakter dalam Pembelajaran, pp. 92-102.

[BI] Bank Indonesia (2013). Pola Pembiayaan Usaha Kecil Menengah Usaha Budidaya Cabai Merah.

URL: http://www.bi.go.id/id/umkm/kelayakan/pola-pembiayaan/holtikultura /Documents/Pola\%20Pembiayaan\%20Usaha\%20Kecil\%20Menengah\%20\%20Budidaya\%20Cabai\%20Merah.pdf

Farid, M. dan Subekti, N. (2012). Tinjauan terhadap Produksi, Konsumsi, Distribusi dan Dinamika Harga Cabe di Indonesia, Buletin Ilmiah Litbang Perdagangan 6(2): 211-233.

Katijaya, S. S. dan Suparti, S. (2013). Regresi Spline Sebagai Alternatif dalam Pemodelan Kurs Rupiah terhadap Dolar Amerika Serikat, Jurnal Gaussian 2(3): 229-238.

Nurdini, A. (2006). "Cross-Sectional VS Longitudinal": Pilihan Rancangan Waktu dalam Penelitian Perumahan Permukiman, DIMENSI (Journal of Architecture and Built Environment) 34(1): pp-52.

S, B. (2009). Sample Code for Fitting a Truncated Polynomial Spline to The Temperatures Observed in Montreal for All of 1961 and 1962. 
URL: $\quad$ http://people.stat.sfu.ca/ cschwarz/Consulting/Trinity/Phase2/Trinity Workshop/Workshop-material-Simon/Intro_to_splines/Exercises/ montreal_temp_5b.R

Saptana, A. N. dan Ar-Rozi, A. M. (2012). Kinerja Produksi dan Harga Komoditas Cabai Merah, Pusat Penelitian Sosial Ekonomi dan Kebijakan Pertanian, Bogor .

Sugiharta, F. (2002). Aplikasi Metode Peramalan terhadap Harga Komoditas Cabai Merah sebagai Dasar Pengambilan Keputusan Para Pelaku Perdagangan, Skripsi, IPB (Bogor Agricultural University).

Sumaryanto (2009). Analisis Volatilitas Harga Eceran Beberapa Komoditas Pangan Utama dengan Model ARCH/GARCH, Jurnal Agro Ekonomi 27(2): 135-163.

Suparti, S. (2013). Analisis Data Inflasi di Indonesia Menggunakan Model Regresi Spline, Media Statistika 6(1): 1-9.

Wu, H. dan Zhang, J.-T. (2006). Nonparametric Regression Methods for Longitudinal Data Analysis: Mixed-Effects Modeling Approaches, Vol. 515, John Wiley \& Sons. 